DOI: $10.17805 /$ zpu.2017.3.10

\title{
Государственная политика в сфере русского языка в контексте Русского мира
}

\author{
О. Н. АСТАФЬЕВА, Н. А. КОЗЛОВЦЕВА \\ РОССИЙСКАЯ АКАДЕМИЯ НАРОДНОГО ХОЗЯЙСТВА И ГОСУДАРСТВЕННОЙ СЛУЖБЫ \\ ПРИ ПРЕЗИДЕНТЕ РОССИЙСКОЙ ФЕДЕРАЦИИ
}

В статье анализируется российская государственная политика в области формирования аутентичного образа Русского мира в сознании граждан Российской Федерации и всего международного сообщества. Русский язык признается базовым конструктом Русского мира. Исходя из этого описываются функции русского языка в качестве субъекта государственной политики, а также его роль как эффективного инструмента реализации политики «мягкой силы».

В современных геополитических условиях актуализировалась роль русского языка в обеспечении национальной безопасности России, в сохранении гражданской идентичности, в понимании культуры и истории народа, в ведении эффективного межнационального и межкультурного диалога не только на территории страны, но и на международной арене. Усиление значения русского языка по всем названным направлениям закреплено в важнейших государственных документах, анализ которых позволил установить комплекс основных его социокультурных задач, связанных с функциями интеграции, социализации, трансляции.

В целях повышения эффективности политики «мягкой силы» Российской Федерации в статье по отношению к русскому языку анализируются ключевые параметры влиятельности языков, применяемые в авторитетных международных рейтингах. Это количество носителей языка, число изучающих язык; экономическая мощь стран, использующих язык; количество областей деятельности, в которых язык является важным; число и население стран, использующих язык; социально-литературный престиж языка, а также официальный статус языка в ООН.

Для определения перспективных направлений развития данной деятельности были проанализированы названные параметры влиятельности языка, цели, задачи и основные приоритеты, содержащиеся в действующих государственных документах (Основах государственной культурной политики, Стратегии государственной культурной политики до 2030 г., Федеральной целевой программе «Русский язык» и др.), на основании которых были установлены достаточность и полнота деятельности государства по продвижению и поддержке русского языка в целях формирования аутентичного образа Русского мира. 
Несмотря на значимость и очевидную полинаправленность государственной деятельности в сфере русского языка, перечень государственных проектов должен быть дополнен с учетом актуального и желаемого образа Русского мира и критериев влиятельности языка, что будет способствовать повышению эффективности политики в данной сфере. Ключевые слова: Русский мир; русский язык; государственная политика; мягкая сила

\section{BВЕАЕНИЕ}

$\mathrm{H}$ а современном этапе общественного, исторического и политического развития России Русский мир в качестве государственной концепции, возникшей после распада Советского Союза, и в качестве трансконтинентальной наднациональной общности, сложившейся значительно раньше и объединившей носителей русского языка и культуры, представляет собой наиболее естественный инструмент политики «мягкой силы» государства, направленный на интеграцию граждан России, соотечественников за рубежом и людей, ощущающих ментальную и духовную близость с русскими, в рамках единой идентичности, а также для трансляции наиболее универсальных ценностных и культурных составляющих «русскости» за границы страны.

Исследования сущности Русского мира проводятся в рамках различных областей социально-гуманитарного знания: философии, культурологии, лингвистики, этнологии, истории, политологии и др. (В. А. Никоновым, Н. А. Нарочницкой, А. В. Павловской, В. А. Тишковым, В. И. Фатющенко и др.).

Опираясь на полученные данными исследователями результаты, Русский мир в наиболее общем смысле можно определить как трансначиональное сочиокультурное nространство, или интегративное поле культуры, основанное на культурных, социальных и личностных взаимодействиях его субъектов, границы которого очерчены ценностями и нормами. Основными конструктами данного пространства, по мнению большинства его исследователей, являются русский язык и основанная на нем русская культура в ее широком понимании как «совокупности формальных и неформальных институтов, явлений и факторов, влияющих на сохранение, производство, трансляцию и распространение духовных ценностей (этических, эстетических, интеллектуальных, гражданских и т. д.)» (Указ Президента ..., 2014: Электронный ресурс), включающей в себя «такие области человеческой практики, как наука, образование, экономика, философия, искусство, литература, политика» (Астафьева, 2013: 23).

Принимая во внимание существующие в научной среде разногласия по вопросу характеристики Русского мира как общности и явления, мы ограничимся прагматическим подходом к нему, согласно которому Русский мир уже сегодня должен не только декларироваться, но и действовать в качестве «мягкой силы» России, что должно быть подкреплено конкретными целями, задачами и мероприятиями, проводимыми в соответствии с ее государственной политикой.

Несмотря на то что в государственных документах стратегического планирования напрямую не фигурирует понятие «Русский мир», в современном политическом дискурсе оно активно используется, объединяя на высшем уровне деятельность государства по популяризации русского языка, культуры и образования на русском языке, поддержке соотечественников за рубежом и реализации иных проектов в гуманитарной сфере.

Понимание русского языка как основы Русского мира обусловливает повышение его значимости в современной государственной политике. С одной стороны, существует понимание деятельности в сфере русского языка как «вопроса государственной 
безопасности России» и ее «стратегического национального приоритета» (Об утверждении ..., 2015: Электронный ресурс), а с другой стороны, была признана его роль как одного из элементов «мягкой силы», осуществляющего достижение внешнеполитических интересов России, а также становление позитивного отношения к ней в мире (Концепция государственной ..., 2015: Электронный ресурс).

Целью данной статьи является характеристика содержания и полноты актуальной государственной политики по формированию образа Русского мира в части русского языка. Аля этого посредством анализа государственных документов, научной и периодической литературы были определены влияние деятельности в сфере русского языка на образ Русского мира, актуальное государственное понимание функциональных ролей русского языка, способы повышения его мировой влиятельности, а также действующие и перспективные направления практической деятельности в данной сфере.

\section{РОАЬ И ФУНКЦИИ РУССКОГО ЯЗЫКА}

Согласно теории межкультурной коммуникации, язык любого народа представляет собой основу его идентичности и оптимальный способ постижения его культуры. С точки зрения лингвистики язык мышления человека (иначе говоря, родной язык) формирует его картину мира, определяет способы взаимодействия с миром, отражает систему ценностей и культуру (Астафьева, 2011). Правила речевого поведения носителей определенного языка и культуры «учитывают то общее - на уровне общечеловеческого, на уровне отдельной социальной формации и национальной культуры, - которое у каждого этноса по-разному преломляется на уровне индивидуального и в различных социальных стратах и профессиональных группах» (Прохоров, 1996: 57).

Русский язык, как и любой другой язык народа, заключает в себе собственный уникальный способ восприятия и концептуализации мира. Выражаемые им значения образуют единую систему взглядов, коллективную философию народа, являющуюся обязательной для всех носителей языка. Такая система в лингвистике получила название языковой картины мира (Апресян, 1995).

Язык нации, по мнению филолога и культуролога А. С. Аихачева, представляет собой алгебраическое выражение всей ее культуры. Ученый писал о конщептосфере языка, понимая под ней конщентрат культуры. Богатство концептосферы языка находится в тесной взаимосвязи со всей национальной культурой, историческим опытом и религией (Иихачев, 1993).

Принимая также во внимание необходимость формирования у современных людей так называемой «глобальной компетентности», подразумевающей способность к коммуникации и сотрудничеству с представителями различных культур на основе взаимного уважения (OECD ... : Электронный ресурс), роль русского языка как официального языка России и Русского мира значительно возрастает.

Таким образом, русский язык имеет важное значение не только как язык общения в границах России, но и в качестве зеркала русской культуры, языка межнационального и межкультурного общения, определяющего границы Русского мира (который называется рядом исследователей «миром русскозвучия»).

Наиболее полный перечень социокультурных ролей русского языка отражен в Концепции государственной поддержки и продвижения русского языка за рубежом. В данном документе русский язык назван:

а) основой истории и культуры России; 
б) государственным языком Российской Федерации;

в) языком международного общения и значимым средством взаимодействия в Содружестве Независимых Государств (СНГ);

г) инструментом этнокультурной и языковой идентификации зарубежных соотечественников;

А) одним из наиболее распространенных языков мира;

е) официальным или рабочим языком крупных международных организаций;

ж) средством формирования позитивного образа нашей страны, а также инструментом российского влияния в мире (Концепция государственной ..., 2015: Электронный ресурс).

Отметим, что названные роли русского языка обладают различной направленностью: внутренней, т. е. при реализации внутренней политики Российской Федерации, и внешней, т. е. проводимой в рамках внешнеполитической деятельности России.

С учетом вышесказанного из множественных функций, которые выполняет язык в культуре, были выделены три ключевые фрнкиии русского языка - интеграционная, социализирующая и трансляционная (Козловцева, 2017: 255), которые считаем возможным дополнить коммуникативной (диалоговой) функиией, являющейся наиболее общей и исконной функцией языка, имеющей принципиальное значение для налаживания межнационального и межкультурного диалога, повышения эффективности публичной риторики и т. д. (табл. 1) (Астафьева, 2008, 2015, 2016).

\section{РУССКИЙ ЯЗЫК КАК ЭАЕМЕНТ ГОСУААРСТВЕННОЙ ПОАИТИКИ «МЯГКОЙ СИАЫ»}

Политика «мягкой силы» в России переживает свое становление и с каждым годом демонстрирует все более высокие результаты. «Мягкая сила», как известно, является одной из форм политической власти, отличительная особенность которой заключается в достижении желаемых результатов посредством симпатии и привлекательности, в отличие от «жесткой силы», основанной на принуждении (Nye, Joseph, 2004). Русский язык является важным әлементом данной политики в аспекте его функции трансляции.

В 2016 г. Россия впервые вошла в топ-30 (заняв 26-е место) самых влиятельных стран мира по эффективности политики «мягкой силы», составленный британским PR-агентством Portland, хотя за год до этого она находилась лишь в топ-50. Аанный рейтинг учитывает объективные и субъективные показатели. К первым относятся государственное управление, бизнес-климат, культурная привлекательность, образование и вовлеченность государства в решение глобальных проблем, а ко вторым - общественное мнение, сформированное на основании результатов опроса 10500 человек в 25 странах мира (Overall Ranking, 2016: Электронный ресурс).

Одним из элементов, формирующих показатель культурной привлекательности страны, является индекс влияния языка, который рассчитывается в соответствии с методикой Ажорджа Вебера (Weber, 1997) на основании шести основных и одного дополнительного параметра.

Параметр 1. Количество носителей языка (по данному параметру присваивается максимум 4 балла). На сегодняшний день русский язык занимает 8-е место в мировом рейтинге по количеству носителей языка.

С момента распада Советского Союза (СССР) в 1991 г. фиксируется значительное уменьшение количества людей, говорящих по-русски. Так, в период существования 
ФУНКЦИИ РУССКОГО ЯЗЫКА

Таблища 1

Table 1

THE FUNCTIONS OF RUSSIAN LANGUAGE

\begin{tabular}{|c|c|c|c|}
\hline Направленность & $\begin{array}{l}\text { Название } \\
\text { функщии }\end{array}$ & Описание функиии & $\begin{array}{c}\text { Влияние на образ } \\
\text { Русского мира }\end{array}$ \\
\hline $\begin{array}{l}\text { Внешняя/ } \\
\text { внутренняя }\end{array}$ & $\begin{array}{l}\text { Коммуникативная } \\
\text { (диалоговая) }\end{array}$ & $\begin{array}{l}\text { Обеспечение налажи- } \\
\text { вания эффективного } \\
\text { межкультурного } \\
\text { и межнационального } \\
\text { дилога между раз- } \\
\text { дичными народами } \\
\text { России, а также } \\
\text { между россиянами } \\
\text { и международным } \\
\text { сообеестом }\end{array}$ & $\begin{array}{l}\text { Коммуникативные стратегии } \\
\text { представителей Русского мира } \\
\text { при налаживании деловых или } \\
\text { повседневных коммуникаций } \\
\text { определяют ту «одежку», } \\
\text { по которой встречают его пред- } \\
\text { ставителей, а также эффектив- } \\
\text { ность реализации всех остальных } \\
\text { функций русского языка, грамот- } \\
\text { ная реализация которых невоз- } \\
\text { можна без налаживания комму- } \\
\text { никативного взаимодействия } \\
\text { на пространстве внутренней } \\
\text { и внешней среды Русского мира }\end{array}$ \\
\hline \multirow[t]{2}{*}{ Внутренняя } & Интеграционная & $\begin{array}{l}\text { Объединение различ- } \\
\text { ных народов России } \\
\text { в единое социокуль- } \\
\text { турное пространство } \\
\text { Русского мира на } \\
\text { базе государственного } \\
\text { языка }\end{array}$ & $\begin{array}{l}\text { Общий уровень грамотности } \\
\text { населения страны, динамика раз- } \\
\text { вития языка и описания его норм, } \\
\text { сохранение общей экологии языка } \\
\text { (сокращение количества заимст- } \\
\text { вованных слов, ненормативной } \\
\text { лексики, нарушений литературной } \\
\text { нормы и т. А.) }\end{array}$ \\
\hline & Социализирующая & \begin{tabular}{|l|} 
Содействие в усвое- \\
нии иностранными \\
гражданами через \\
русский язык образ- \\
цов поведения, социо- \\
культурных норм \\
и ценностей Русского \\
мира для успешного \\
существования в рос- \\
сийском обществе
\end{tabular} & $\begin{array}{l}\text { Непосредственный процесс взаи- } \\
\text { модействия с русскими в рамках } \\
\text { языковой среды, а также через } \\
\text { специальные курсы русского язы- } \\
\text { ка, отбор материала для которых } \\
\text { должен быть основан на принци- } \\
\text { пах релевантности современной } \\
\text { жизни русских, практической } \\
\text { применимости и коммуникативной } \\
\text { значимости }\end{array}$ \\
\hline Внешняя & Трансляционная & $\begin{array}{l}\text { Передача релевант- } \\
\text { ной информации } \\
\text { о России и Русском } \\
\text { мире в зарубежные } \\
\text { страны, формирова- } \\
\text { ние их адекватного } \\
\text { образа на междуна- } \\
\text { родной арене }\end{array}$ & $\begin{array}{l}\text { Содержание учебных пособий и } \\
\text { научно-методической литературы } \\
\text { по обучению русскому языку как } \\
\text { иностранному и основанного на } \\
\text { них учебного процесса, так как в } \\
\text { отсутствие языковой среды у обу- } \\
\text { чающихся они являются практиче- } \\
\text { ски единственным каналом получе- } \\
\text { ния информации о России и Рус- } \\
\text { ском мире, вследствие чего при } \\
\text { отборе материала должны учиты- } \\
\text { ваться задачи развенчания стерео- } \\
\text { типных представлений о России } \\
\text { и создания адекватного образа со- } \\
\text { временной России и Русского мира }\end{array}$ \\
\hline
\end{tabular}


СССР на русском языке, по различным данным, говорили до 500 млн человек в мире. В 2012 г. это число составило уже только 250 млн человек. Прогнозируется, что оно продолжит уменьшаться и к 2025 г. снизится до 215 млн человек, а до 2050 г. сократится еще вдвое и составит 130 млн человек (Арефьев, 2012: Электронный ресурс). ОАнако, согласно данным 2016 г., отмечается, что русским языком как родным владеют 267912330 человек в мире (из них 154 млн человек на территории России) (Summary by language size: Электронный ресурс).

Параметр 2. Число изучающих язык (лаксимум 6 баллов).

Русский язык занимает 6-е место в мире по общему количеству людей, говорящих на нем, после английского, китайского, хинди, испанского и арабского. Однако данное положение в рейтинге также имеет тенденцию к снижению.

По официальным данным, общее количество постоянно изучающих русский язык взрослых иностранцев составляет порядка 10,5 млн человек. При этом число школьников, обучающихся на русском языке в бывших республиках Советского Союза, составляет около 3,2 млн человек, в иных иностранных государствах $-1,3$ млн школьников и около 230 тыс. студентов вузов. Также организуются курсы русского языка при российских центрах науки и культуры за рубежом, на которых обучаются порядка 19 тыс. человек в год (Об утверждении федеральной ... , 2015: Электронный ресурс).

Аанные последних исследований свидетельствуют о востребованности специалистов со знанием русского языка, а следовательно, и о росте спроса на изучение русского языка в мире, который составляет на сегодняшний день 125 млн человек. Из них более 100 млн приходится на страны Содружества Независимых Государств (СНГ), по 3 млн человек необходимы в странах Европы и в Китае, по 2 млн - в странах Северной Америки и Африки, около 1,5 млн человек - в странах БРИКС (кроме Китая), по 1 млн в странах ACEAH, Японии, Корее, а также в странах Арабского мира (Новые данные о ..., 2016: Электронный ресурс).

Параметр 3. Экономическая мощь стран, использующих язьюк (максимум 8 баллов).

Согласно данным Всемирного банка, Россия является шестой экономикой мира по ВВП, рассчитанному по паритету покупательской способности (ППС). Однако русский язык имеет официальный статус не только на территории Российской Федерации, но и в ряде иных стран и территорий, учет экономического уровня развития которых также важен для определения значения данного параметра.

Так, русский язык считается государственным (официальным) языком Белоруссии (71-е место ВВП по ППС), Южной Осетии, Приднестровья, Аонецкой и Ауганской народных республик (данные страны не вкдючены в рейтинг в связи с их неполной признанностью мировым сообществом).

Государственным языком с правовыми ограничениями он считается в Киргизии (141-е место), Казахстане (42-е место) и Абхазии (не включена в рейтинг).

В ряде государств или их областей русский язык обладает отдельными функциями официального языка (например, де-факто используется в отдельных государственных организациях или документообороте), в частности в регионах Молдавии (145-е место), Украины (49-е место), Румынии (43-е место), США (2-е место), Таджикистана (135-е место), Узбекистана (64-е место) и Израиля (53-е место).

Помимо этого, русский язык является языком национального меньшинства в Армении (132-е место), Польше (23-е место) и Словакии (72-е место) (Gross domestic product ..., 2016: Электронный ресурс). 
Параметр 4. Количество основных областей человеческой и культурной деятельности, в которых язык является важныл (максимум 8 баллов).

Русский язык имеет огромное значение для мирового сообщества, являясь одним из важнейших инструментов познания другими народами непреходящих гуманистических ценностей российской культуры, образования и науки.

Современная Россия и Русский мир обладают одной из ведущих мировых культурных систем, базирующейся на русском языке и включенной в общемировой культурный багаж. Каждому современному человеку в мире вне зависимости от национальности или рода деятельности, для того чтобы считать себя истинно образованным, необходимо быть знакомым с произведениями Аостоевского, Чехова, Чайковского или Кандинского (Смыслы и ценности ..., 2010: 76).

Помимо этого, русский язык является официальным или рабочим языком более 20 международных организаций, регулирующих различные сферы человеческой деятельности.

Параметр 5. Число и население стран, используюших язык (максимум 7 баллов).

По данным международных исследований, русский язык сегодня используется в 19 странах мира (Summary by language size: Электронный ресурс). В совокупности население данных стран составляет более полумиллиарда человек, т. е. чуть менее 7\% от общемировой численности населения. Однако, по данным исследователей Русского мира, на современной карте мира не существует ни одной страны, в которой не жили бы выходцы из России, не говорили бы и не думали бы на русском языке.

Параметр 6. Сочиально-литературный престиж языка (максимум 4 балла).

Степень влиятельности языка также во многом зависит и от его роли в сети распространения знаний. Аанный показатель приобретает особую значимость в контексте перехода мировой цивилизации в постиндустриальную эпоху, характеризующуюся, в том числе, формированием общества знания. В связи с этим возрастает роль языков как средства передачи новых знаний.

Учитывая же тот факт, что множество новых знаний и инноваций продуцируются в специальных научных кластерах (таких, как, например, Силиконовая долина в США или Сколково в России), то языком их распространения в первой инстанции становится или язык ученых-разработчиков, или же международный язык науки - английский. Научные коллективы таких кластеров, как известно, мультинациональны. Например, по-русски в соответствии со статистикой говорит треть Силиконовой долины и, соответственно, большая часть представителей Сколкова.

Проведенное в 2014 г. исследование мировых языков как инструментов распространения знаний было основано на трех источниках данных:

- результатах проекта ЮНЕСКО Index Translatorium, определяющего уровень переводимости языков и направления осуществления переводов;

- постах двуязычных пользователей социальной сети Twitter;

- статистике правок дву- и мультиязычных пользователей в Википедии (Ronen et all., 2014: Электронный ресурс).

В результате авторами исследования были сформированы сети влияния языков. Так, согласно сети книжных переводов (электронная база данных которых составляет более двух млн записей о 500000 авторов и 78000 издателей в 148 странах мира), русский является одним из самых переводимых языков в мире. В рейтинге языков, с которых чаще всего делают переводы, русский занимает четвертое место. Среди же языков, на которые переводится большинство книг, русский находится на седьмом 
месте. Отметим, что русский язык зачастую является языком-источником или языком-посредником для переводов на языки стран СНГ.

В Википедии и Твиттере русский язык по степени использования занимает второе место, значительно уступая находящемуся на первом месте английскому.

Авторы исследования также обнаружили тесную взаимосвязь между влиятельностью языка и совокупностью говоривших на нем известных на весь мир личностей разных эпох. Так, например, русскоязычных известных людей с 1800 по 1950 г. названо 272, при этом в России из них проживали 240 человек (там же).

Также большое значение для определения социально-литературного престижа современного русского языка играет то, что в последние годы русскоязычный Интернет занял первое место в Европе по количеству и активности пользователей, второе место в мире по объемам создания и потребления русскоязычного контента и по количеству национальных доменов, утвердившись тем самым в международном киберпространстве.

Аополнительным параметром при расчете индекса влиятельности языка является его официальный статус в Организачии Объединенньх Начий (ООН). За это ему присваивается дополнительньй балл. Русский язык, как известно, является одним из шести официальных языков ООН.

Сегодня русский язык по индексу влиятельности занимает четвертое место в мире вслед за английским, французским и испанским языками соответственно (10 самых ... : Электронный ресурс).

На основании описанных параметров влиятельности и приведенных данных о текущих позициях русского языка выделим возможные пути повышения его влиятельности в мире: рации;

- увеличение количества изучающих русский язык вне границ Российской Феде-

- расширение перечня областей использования русского языка;

- повышение социально-литературного престижа русского языка (в том числе за счет поддержки и популяризации русскоязычной культуры);

- повышение информированности мирового сообщества о языковой политике, проводимой Российской Федерацией.

\section{АКТУААЬНЫЙ ОБРАЗ РУССКОГО МИРА \\ В СОЗААНИИ СОЦИУМА}

Определив функциональные роли русского языка и показатели, необходимые для повышения его влиятельности в мире, можно утверждать, что русский язык на сегодняшний день обладает определенным весом и влиянием в глобальном пространстве. Посредством русского языка формируется и может корректироваться образ Русского мира.

Аля получения современных данных о текущем образе Русского мира в сознании социума в 2015-2016 гг. нами был проведен опрос среди россиян, соотечественников за рубежом и иностранцев в социальных сетях ВКонтакте и Facebook, в котором приняли участие 759 человек из 69 стран мира (303 иностранца, 288 соотечественников за рубежом и 168 россиян).

Задачей опроса было определение признаков русскости, отраженных в общественном сознании. Респондентам было предложено написать три ассоциации со словосочетанием «Русский мир». Всего было получено более 250 различных вариантов. Были 
названы элементы русской культуры, персоналии, блюда русской кухни, топонимические наименования, моральные и мировоззренческие ценности Русского мира.

Основными элементами русской культуры, по мнению респондентов, являются православие как доминирующая религия (27\%), традиции и обычаи (12\%), литература $(12 \%)$, искусство $(6 \%)$, балет $(6 \%)$, Новый год $(3 \%)$, музыка $(2 \%)$.

Среди выдающихся представителей Русского мира опрошенными названы В. В. Путин $(32 \%)$, А. С. Пушкин $(29 \%), \Lambda$. Н. Толстой $(10 \%)$, Ф. М. Аостоевский $(9 \%)$, П. И. Чайковский (6\%), М. А. Булгаков и Ю. А. Гагарин (по 2\%). Отметим, что среди названных личностей большинство являются деятелями культуры, за исключением действующего Президента, который, очевидно, является для них лицом современной России.

Ключевыми элементами русской кухни для респондентов являются блины (24\%), борщ (13\%), чай (9\%), салат оливье (7\%), икра (4\%), гречневая каша (4\%), зефир, квас, селедка, соленья, докторская колбаса, пельмени (по 2\%).

Важнейшими географическими координатами Русского мира для опрошенных являются Москва (54\%), Санкт-Петербург (19\%), Сибирь (13\%), Волга (8\%), Золотое кольцо и Транссибирская магистраль (по $3 \%$ ).

Значимым является мнение опрошенных о моральных качествах и мировоззренческих ценностях, присущих Русскому миру. 10\% респондентов назвали определяющим качеством силу этого мира, 9\% - справедливость, $8 \%$ - любовь и дружбу, 6\% - свободу и красоту, $5 \%$ - стойкость, доброту и взаимопомощь.

Отметим, что при определении Русского мира некоторыми соотечественниками даются негативные характеристики (такие, как агрессия, обман). Около 8\% всех опрошенных отмечали, что с их точки зрения Русский мир является искусственно созданной политической идеологией. Учет данной точки зрения также необходим для формирования релевантного образа Русского мира.

Анкетирование также выявило значительное количество стереотипных представлений о Русском мире, формирующих клишированное мнение о России. Так, $16 \%$ респондентов ассоциируют Русский мир с водкой, 13\% - с матрешкой, 12\% с балалайкой, 7\% - с зимой, вьюгой и холодами, 3\% - с медведями, борщом, баней и т. А.

Результаты проведенного опроса позволяют сделать вывод о том, что актуальный образ Русского мира достаточно клиширован и основывается в первую очередь на традиционных представлениях о России и русской культуре, не включая в себя практически никаких элементов современности. Такая высокая традиционность данного образа является катализатором появления все большего количества стереотипов о Русском мире, а также негативного мнения о нем. В связи с этим важным направлением политики по формированию образа Русского мира (в том числе и в аспекте русского языка) видится работа по развенчанию стереотипов и созданию образа современной разнообразной поликультурной России.

\section{ОСНОВНЫЕ НАПРАВАЕНИЯ ГОСУААРСТВЕННОЙ ПОАИТИКИ В СФЕРЕ РУССКОГО ЯЗЗЫКА}

Согласно документам основные ресурсы в сфере языковой политики Российского государства направлены на достижение следующих целей:

а) повышение мировой значимости и конкурентоспособности русского языка (Концепция государственной ... , 2015: Электронный ресурс); 
б) развитие русского языка как государственного языка и как языка межнационального общения народов России;

в) обеспечение әффективности и доступности системы изучения русского языка как родного, неродного и иностранного;

г) развитие кадрового и методического потенциала в сфере обучения русскому языку как родному, неродному и иностранному (Об утверждении федеральной ... , 2015: Электронный ресурс).

Как уже отмечалось, данная деятельность имеет два основных направления: внутреннее (пункты «б»- «г») и внешнее (пункты «а», «в», «г»). Отметим, что отдельные задачи имеют связи только с одним из направлений («а» и «б»), а другие охватывают оба («в» и «Г»).

По каждому из направлений деятельности можно выделить основные целевые группы, которым адресованы отдельные мероприятия. В рамках внешней деятельности можно выделить соотечественников за рубежом, граждан стран СНГ и граждан иных зарубежных стран. В рамках внутренней деятельности выделяются профессионалы в сфере русского языка, народы России, иностранные граждане, желающие работать, учиться или жить в России.

В табл. 2 и 3 приведены результаты анализа государственных документов, регулирующих сферу русского языка, подробно представлена внешняя (табл. 2, с. 132-133) и внутренняя (табл. 3, с. 134-135) деятельность государства по каждому из направлений, а также предлагаемые нами дополнительные возможные направления данной деятельности.

Также отметим, что необходима дальнейшая декомпозиция третьего направления внешнеполитической деятельности в сфере русского языка, а именно разработка особых условий и мероприятий для стран БРИКС, АСЕАН, стран Европы, Африки, Северной Америки и т. А.

Отметим также, что на сегодняшний день государственная политика России в сфере русского языка отличается своей масштабностью и разветвленностью, а также значительным финансированием (рост объема финансирования третьей Федеральной целевой программы «Русский язык» по сравнению с первой вырос в 5,35 раза). Однако по каждому из существующих направлений данной деятельности необходим рост, который, по нашему мнению, будет способствовать созданию современного образа Русского мира как на территории России, так и за рубежом.

\section{ЗАКАЮЧЕНИЕ}

Русский язык для России и Русского мира является не только основным средством коммуникации, но и инструментом политического влияния, способствующим при грамотном использовании урегулированию текущего и потенциальных международных конфликтов, межнациональному пониманию и взаимодействию.

Текущие направления государственной деятельности в данной сфере демонстрируют ее полинаправленность, однако думается, что данный перечень может быть расширен и дополнен с учетом актуального и желаемого образа Русского мира и критериев влиятельности языка, что будет способствовать повышению әффективности политики в данной сфере, а следовательно, и формированию аутентичного образа России и Русского мира на международной арене. 


\section{ОСНОВНЫЕ НАПРАВАЕНИЯ ВНЕШНЕПОАИТИЧЕСКОЙ АЕЯТЕАЬНОСТИ РОССИИ В СФЕРЕ РУССКОГО ЯЗЫКА}

Table 2

THE MAIN DIRECTIONS OF RUSSIA'S FOREIGN POLICY IN THE SPHERE OF RUSSIAN LANGUAGE

\begin{tabular}{|c|c|c|}
\hline $\begin{array}{c}\text { Целевая аудитория } \\
\text { внешнеполитиче- } \\
\text { ской деятельности } \\
\text { России в сфере } \\
\text { русского язька }\end{array}$ & $\begin{array}{c}\text { Обозначенные в государственных документах } \\
\text { направления деятельности }\end{array}$ & $\begin{array}{c}\text { Аополнительные } \\
\text { возможные } \\
\text { направления } \\
\text { деятельности }\end{array}$ \\
\hline $\begin{array}{l}\text { 1. Соотечественни- } \\
\text { ки за рубежом }\end{array}$ & $\begin{array}{l}\text { а) организационная и научно-методическая под- } \\
\text { держка русских школ и классов за рубежом; } \\
\text { б) поставка учебников, учебных пособий, научно- } \\
\text { популярных книг и журналов по русскому языку } \\
\text { в иностранные государства; } \\
\text { в) создание мотивации к изучению русского языка } \\
\text { у потомков выходцев из России; } \\
\text { г) подготовка и переподготовка специалистов в об- } \\
\text { ласти русского языка из числа соотечественников, } \\
\text { проживающих за рубежом, в высших учебных за- } \\
\text { ведениях России; } \\
\text { д) формирование и развитие партнерской сети } \\
\text { «Интитут Пушкина»; } \\
\text { е) техническое, учебно-методическое обеспечение } \\
\text { единого электронного образовательного прост- } \\
\text { ранства для обучения русскому языку на всех } \\
\text { уровнях подготовки, а также обеспечение широ- } \\
\text { кой вариативности программ; } \\
\text { ж) проведение комплекса по укреплению и повы- } \\
\text { шению популярности и престижа русского языка; } \\
\text { з) поддержка зарубежных русскоязычных писате- } \\
\text { лей и ученых; } \\
\text { и) обеспечение системной поддержки, оказывае- } \\
\text { мой зарубежным организациям в укреплении по- } \\
\text { зиций русского языка }\end{array}$ & $\begin{array}{l}\text { а) придание русскому } \\
\text { языку статуса языка } \\
\text { национального мень- } \\
\text { шинства в странах } \\
\text { формирования круп- } \\
\text { ных русскоязычных } \\
\text { диаспор; } \\
\text { б) разносторонняя } \\
\text { поддержка страновых } \\
\text { организаций соотече- } \\
\text { ственников; } \\
\text { в) организационная и } \\
\text { научно-методическая } \\
\text { поддержка русско- } \\
\text { язычных кдубов } \\
\text { соотечественников } \\
\text { за рубежом; } \\
\text { г) поддержка русско- } \\
\text { язычного бизнеса за } \\
\text { рубежом }\end{array}$ \\
\hline $\begin{array}{l}\text { 2. Граждане стран } \\
\text { СНГ }\end{array}$ & $\begin{array}{l}\text { а) развитие внешнеполитического диалога по во- } \\
\text { просам сохранения русского языка на основе норм } \\
\text { международного права; } \\
\text { б) разработка и реализация программ сохранения } \\
\text { и укрепления исторически сложившихся позиций } \\
\text { русского языка; } \\
\text { в) совершенствование методик изучения и препо- } \\
\text { давания русского языка; } \\
\text { г) подготовка, переподготовка и повышение квали- } \\
\text { фикации преподавателей русского языка; } \\
\text { д) разносторонняя поддержка образовательных } \\
\text { организаций, преподающих русский язык (в том } \\
\text { числе посредством формирования и развития } \\
\text { партнерской сети «Институт Пушкина»); } \\
\text { е) поддержка преподавания русского языка в рос- } \\
\text { сийско-национальных образовательных учрежде- } \\
\text { ниях и в российских учебно-методических цент- } \\
\text { рах; }\end{array}$ & $\begin{array}{l}\text { а) придание русскому } \\
\text { языку статуса офици- } \\
\text { ального в каждой из } \\
\text { стран СНГ; } \\
\text { б) введение изучения } \\
\text { русского языка в ка- } \\
\text { честве первого иност- } \\
\text { ранного в школах, } \\
\text { высших учебных заве- } \\
\text { дениях стран СНГ }\end{array}$ \\
\hline
\end{tabular}




\begin{tabular}{|c|c|c|}
\hline $\begin{array}{c}\text { Целевая аудитория } \\
\text { внешнеполитиче- } \\
\text { ской деятельности } \\
\text { России в сфере } \\
\text { русского языка }\end{array}$ & $\begin{array}{c}\text { Обозначенные в государственных документах } \\
\text { направления деятельности }\end{array}$ & $\begin{array}{c}\text { Аополнительные } \\
\text { возложные } \\
\text { направления } \\
\text { деятельности }\end{array}$ \\
\hline & $\begin{array}{l}\text { ж) проведение масштабных комплексных акций } \\
\text { и мероприятий, направленных на поддержку рус- } \\
\text { ского языка (прежде всего Аня русского языка); } \\
\text { 3) техническое, учебно-методическое обеспечение } \\
\text { единого электронного образовательного прост- } \\
\text { ранства для обучения русскому языку на всех } \\
\text { уровнях подготовки, а также обеспечение широ- } \\
\text { кой вариативности программ; } \\
\text { и) расширение присутствия русского языка в сети } \\
\text { «Итернет»; } \\
\text { к) обеспечение поддержки зарубежных структур } \\
\text { в укреплении позиций русского языка }\end{array}$ & \\
\hline $\begin{array}{l}\text { 3. Граждане стран } \\
\text { ближнего } \\
\text { и дальнего } \\
\text { зарубежья }\end{array}$ & $\begin{array}{l}\text { а) проведение масштабных комплексных акций } \\
\text { и мероприятий, направленных на распространение } \\
\text { русского языка (прежде всего Аня русского языка); } \\
\text { б) формирование единой государственной систе- } \\
\text { мы курсового обучения русскому языку за рубе- } \\
\text { жом, ее обеспечение научными, учебно-методи- } \\
\text { ческими, материально-техническими, кадровыми } \\
\text { и иными ресурсами; } \\
\text { в) расширение использования дистанционных об- } \\
\text { разовательных технологий при обучении русскому } \\
\text { языку; } \\
\text { г) расширение и совершенствование системы ко- } \\
\text { мандирования российских преподавателей и спе- } \\
\text { циалистов в области русского языка в зарубежные } \\
\text { образовательные организации; } \\
\text { А) оказание разностороннего содействия зарубеж- } \\
\text { ным образовательным организациям, осуществя- } \\
\text { ющим преподавание русского языка; } \\
\text { е) подготовка, переподготовка, повышение квали- } \\
\text { фикации зарубежных преподавателей русского } \\
\text { языка; } \\
\text { ж) поддержка функционирования российской го- } \\
\text { сударственной системы тестирования по русскому } \\
\text { языку как иностранному; } \\
\text { з) формирование и развитие партнерской сети } \\
\text { «Институт Пушкина»; } \\
\text { и) обеспечение единого электронного образова- } \\
\text { тельного пространства для обучения русскому } \\
\text { языку на всех уровнях подготовки и широкой ва- } \\
\text { риативности программ; } \\
\text { к) обеспечение доступа изучающих русский язык } \\
\text { за рубежом к электронным ресурсам библиотек } \\
\text { России; } \\
\text { д) расширение присутствия русского языка в сети } \\
\text { «Интернет»; } \\
\text { м) обеспечение системной поддержки зарубежным } \\
\text { структурам в укреплении позиции русского языка }\end{array}$ & $\begin{array}{l}\text { а) введение изучения } \\
\text { русского языка как } \\
\text { второго-четвертого } \\
\text { иностранного в сред- } \\
\text { них и высших зару- } \\
\text { бежных образователь- } \\
\text { ных организациях; } \\
\text { б) развитие системы } \\
\text { государственного тес- } \\
\text { тирования по русско- } \\
\text { му языку как иност- } \\
\text { ранному с целью } \\
\text { удовлетворения раз- } \\
\text { нообразных образова- } \\
\text { тельных потребностей } \\
\text { иностранных граждан; } \\
\text { в) разносторонняя } \\
\text { поддержка организа- } \\
\text { ций, ведущих бизнес } \\
\text { с Россией на русском } \\
\text { языке; } \\
\text { г) поддержка русско- } \\
\text { язычных средств мас- } \\
\text { совой информации } \\
\text { за рубежом }\end{array}$ \\
\hline
\end{tabular}


ОСНОВНЫЕ НАПРАВАЕНИЯ ВНУТРИПО ИТИЧЕСКОЙ АЕЯТЕАЬНОСТИ РОССИИ

Таблица 3 В СФЕРЕ РУССКОГО ЯЗЫКА

THE MAIN DIRECTIONS OF RUSSIA'S DOMESTIC POLICY

Table 3 IN THE SPHERE OF RUSSIAN LANGUAGE

\begin{tabular}{|c|c|c|}
\hline $\begin{array}{c}\text { Целевая } \\
\text { аудитория внутри- } \\
\text { политической } \\
\text { деятельности } \\
\text { России В сфере } \\
\text { русского языка }\end{array}$ & $\begin{array}{c}\text { Обозначенные В государственных } \\
\text { документах направления } \\
\text { деятельности }\end{array}$ & $\begin{array}{c}\text { Аополнительные возможные } \\
\text { направления деятельности }\end{array}$ \\
\hline $\begin{array}{l}\text { 1. Профессионалы } \\
\text { в сфере русского } \\
\text { языка }\end{array}$ & $\begin{array}{l}\text { а) проведение научно-исследователь- } \\
\text { ских работ в области функцонирова- } \\
\text { ния, развития и изучения русского } \\
\text { языка; } \\
\text { б) формирование аналитического } \\
\text { и организационно-нормативного } \\
\text { обеспечения фунцционирования } \\
\text { и изучения русского языка; } \\
\text { в) доработка и издание комплекса } \\
\text { грамматик и словарей, содержащих } \\
\text { нормы современного русского лите- } \\
\text { ратурного языка; } \\
\text { г) развитие кадрового потенциала } \\
\text { в сфере русского языка }\end{array}$ & $\begin{array}{l}\text { a) разработка и постоянное обнов- } \\
\text { ление единого портала, посвящен- } \\
\text { ного нормам современного рус- } \\
\text { ского языка; } \\
\text { б) определение качественных кри- } \\
\text { териев эффективности исследова- } \\
\text { ний в сфере русского языка, на ос- } \\
\text { новании которых будет обеспечи- } \\
\text { ваться финансирование данной } \\
\text { сферы }\end{array}$ \\
\hline 2. Народы России & $\begin{array}{l}\text { а) проведение масштабных комплекс- } \\
\text { ных акций и мероприятий (прежде } \\
\text { всего Аня русского языка) для под- } \\
\text { держки русского языка, а также } \\
\text { повышение его популярности } \\
\text { и престижа; } \\
\text { б) разностороннее обеспечение еди- } \\
\text { ного электронного образовательного } \\
\text { пространства для овладевающих } \\
\text { русским языком на всех уровнях } \\
\text { подготовки; } \\
\text { в) подготовка, переподготовка и по- } \\
\text { вышение квалификации преподавате- } \\
\text { лей русского языка }\end{array}$ & $\begin{array}{l}\text { а) государственная поддержка за- } \\
\text { рекомендовавших себя акций и ме- } \\
\text { роприятий, направленных на по- } \\
\text { вышение грамотности жителей } \\
\text { России (например, «Тотальный } \\
\text { диктант»); } \\
\text { б) пересмотр учебников и про- } \\
\text { грамм обучения русскому языку с } \\
\text { точки зрения современных образо- } \\
\text { вательных методик и особенностей } \\
\text { восприятия учащихся; } \\
\text { в) включение требований к уровню } \\
\text { владения русским языком во все } \\
\text { профессиональные стандарты, } \\
\text { а также обеспечение контроля гра- } \\
\text { мотности сотрудников со стороны } \\
\text { работодателей }\end{array}$ \\
\hline $\begin{array}{l}\text { 3. Иностранные } \\
\text { граждане, желаю- } \\
\text { щие работать, } \\
\text { учиться или жить } \\
\text { в России }\end{array}$ & $\begin{array}{l}\text { а) создание условий для языковой } \\
\text { адаптации мигрантов; } \\
\text { б) создание благоприятной среды для } \\
\text { обучения иностранных граждан рус- } \\
\text { скому языку в объемах, необходимых } \\
\text { для их трудовой деятельности в России; }\end{array}$ & $\begin{array}{l}\text { a) пересмотр требований, формата } \\
\text { и принципов организации системы } \\
\text { тестирования по русскому языку } \\
\text { для трудящихся мигрантов, а так- } \\
\text { же желающих получить вид на жи- } \\
\text { тельство или гражданство России; }\end{array}$ \\
\hline
\end{tabular}




\begin{tabular}{|c|c|c|}
\hline $\begin{array}{c}\text { Целевая } \\
\text { аудитория внутри- } \\
\text { политической } \\
\text { деятельности } \\
\text { России в сфере } \\
\text { русского язика }\end{array}$ & $\begin{array}{c}\text { Обозначенные в государственных до- } \\
\text { кументах направления } \\
\text { деятельности }\end{array}$ & $\begin{array}{c}\text { Аополнительные Возможные } \\
\text { направления деятельности }\end{array}$ \\
\hline & $\begin{array}{l}\text { в) техническое, учебно-методическое } \\
\text { обеспечение единого электронного } \\
\text { образовательного пространства для } \\
\text { обучения русскому языку; } \\
\text { г) обеспечение широкой вариативнос- } \\
\text { ти программ обучения русскому язы- } \\
\text { ку с использованием дистанционных } \\
\text { технологий; } \\
\text { д) подготовка, переподготовка, повы- } \\
\text { шение квалификации преподавателей } \\
\text { русского языка }\end{array}$ & $\begin{array}{l}\text { б) введение обязательного госу- } \\
\text { дарственного тестирования для } \\
\text { иностранных граждан, поступаю- } \\
\text { щих в российские высшие учебные } \\
\text { заведения (вузы); } \\
\text { в) введение единого стандарта и } \\
\text { программ подготовки иностран- } \\
\text { ных граждан к обучению в вузах } \\
\text { России }\end{array}$ \\
\hline
\end{tabular}

\section{СПИСОК АИТЕРАТУРЫ}

Концепция государственной поддержки и продвижения русского языка за рубежом (2015) [Электронный ресурс] // Президент России. URL: http://kremlin.ru/acts/news/50644 (дата обращения: 03.05.2017).

Об утверждении федеральной целевой программы «Русский язык» на 2016-2020 годы (2015) [Электронный ресурс] // Правительство России. URL: http://government.ru/docs/18169/ (дата обращения: 03.05.2017).

Указ Президента Российской Федерации от 24 декабря 2014 г. № 808 «Об утверждении Основ государственной культурной политики» (2014) [Электронный ресурс]// Президент России. URL: http://kremlin.ru/acts/bank/39208 (дата обращения: 03.05.2017).

Апресян, Ю. А. (1995) Образ человека по данным языка: попытка системного описания // Вопросы языкознания. № 1. С. 7-15.

Арефьев, А. А. (2012) Русский язык на рубеже XX-XXI веков [Электронный ресурс] // Центр социального прогнозирования и маркетинга. URL: https://www.civisbook.ru/files/File/ russkij_yazyk.pdf (дата обращения: 03.05.2017).

Астафьева, О. Н. (2008) Межкультурный диалог в условиях глобализации: проблемы теории и практики // Межкультурный и межрелигиозный диалог в целях устойчивого развития: Материалы Международной конференции / под. ред. В. К. Егорова. М. : Изд-во РАГС. C. $120-138$.

Астафьева, О. Н. (2011) Русский язык в контексте современных стратегий и практик культурной политики // Кириллица: от возникновения до наших дней. СПб. : Алетейя. С. 419-443.

Астафьева, О. Н. (2013) Культурная политика: теоретические аспекты и практика реализации // Современная наука: актуальные проблемы теории и практики. Серия: Гуманитарные науки. № 1-2. С. 22-29.

Астафьева, О. Н. (2015) Межкультурные коммуникации и коллективная идентичность: новые акценты в культурной политике национальных государств [Электронный ресурс] // XV Международные Ихачевские научные чтения, 2015 год. «Современные глобальные вызовы и национальные интересы»: материалы и выступления. URL: http://www.lihachev.ru/pic/site/ files/lihcht/2015/dokladi/AstafjevaON_sec2_rus_izd.pdf (дата обращения: 13.05.2017).

Астафьева, О. Н. (2016) Межкультурный диалог в контексте традиций и новаций: согласование индивидуальных и коллективных дискурсов // Россия: государство и общество в новой реальности : сб. статей Международной научно-практической конференции ИГСУ РАНХиГС : в 3 т. М. : РАНХиГС. Т. 3.528 с. С. 133-139. 
Козловцева, Н. А. (2017) Программы и проекты по продвижению и поддержке русского языка в структуре государственной политики Российской Федерации : сб. статей Международной научно-практической конференции «Государственное управление и развитие России: модели и проекты». М. : Проспект. Т. 3.840 с. С. 253-260.

Аихачев, А. С. (1993) Концептосфера русского языка // Известия Академии наук. Серия литературы и языка. Т. 52. № 1. С. 3-9.

Новые данные о востребованности русского языка за рубежом (2016) / Государственный институт русского языка им. А. С. Пушкина. URL: http://www.pushkin.institute/news/detail. php?ID=4942 (дата обращения: 03.05.2017).

Прохоров, Ю. Е. (1996) Национальные социокультурные стереотипы речевого общения и их роль в обучении русскому языку иностранцев. М. : Педагогика-Пресс. 216 с.

Смыслы и ценности Русского мира (2010): сб. статей и материалов круглых столов, организованных фондом «Русский мир» / под ред. В. Никонова. М. : Русский мир. 112 с.

10 самых влиятельных языков мира [Электронный ресурс]// Бюро переводов «Прима Виста». URL: http://www.primavista.ru/rus/catalog/vliyatelnye_yazyki (дата обращения: 03.05.2017).

Gross domestic product based on purchasing-power-parity (PPP) valuation of country GDP (2016) [Электронный ресурс] // The World Bank. URL: http://data.worldbank.org/indicator/ NY.GDP.MKTP.PP.CD (дата обращения: 03.05.2017).

OECD proposes new approach to assess young people's understanding of global issues and attitudes toward cultural diversity and tolerance [Электронный ресурс] // OECD. URL: https:// www.oecd.org/pisa/oecd-proposes-new-approach-to-assess-young-peoples-understanding-of-global-issues-and-attitudes-toward-cultural-diversity-and-tolerance.htm (дата обращения: 22.04.2017).

Overall Ranking (2016) [Электронный ресурс] // The Soft Power 30. URL: http://softpower30.portland-communications.com/ranking/ (дата обращения: 03.05.2017). 193 p.

Nye, Jr., Joseph, S. (2004) Soft Power. The means to success in world politics. N.Y.: Public Affairs.

Ronen, Sh., Gonçalves, B., Hu, K., Vespignani, A., Pinker, S., Hidalgo, C. (2014) Links that speak: The global language network and its association with global fame // Proceedings of the National Academy of Sciences of the United States of America, vol. 111, no. 52. DOI: 10.1073/pnas.1410931111

Summary by language size [Электронный ресурс]// Ethnologue: Languages of the World. URL: http://www.ethnologue.com/statistics/size (дата обращения: 22.04.2017)

Weber, G. (1997) The world's 10 most influential languages // Language Monthly. № 3. P. 12-18.

Аата поступления: 13.05.2017 2.

\section{STATE POLICY IN THE SPHERE OF THE RUSSIAN LANGUAGE \\ IN THE CONTEXT OF THE RUSSIAN WORLD \\ O. N. Astafieva, N. A. Kozlovtseva \\ the Russian Presidential Academy of National Economy and Public Administration}

This article examines the Russian state policy in the aspect of forming an authentic image of the Russian world in the minds of the citizens of the Russian Federation and the entire international community. The Russian language is recognized as the basic construct of the Russian world. Based on this, the functions of the Russian language as a subject of the state policy are described, as well as its role as an effective instrument for implementing the policy of "soft power".

In modern geopolitical conditions, the role of the Russian language was actualized in ensuring Russia's national security, preserving the civil identity, understanding the culture and history of the people, in maintaining an effective interethnic and intercultural dialogue not only on the territory of the country, but also on the international stage. The strengthening of the importance of the Russian language in all these areas is enshrined in the most important state documents, the analysis of which has made it possible to establish a set of its main socio-cultural tasks related to the functions of integration, socialization, and broadcasting. 
In order to improve the effectiveness of the soft power policy of the Russian Federation, the article analyzes the key parameters of the influence of the languages used in authoritative international rankings in relation to the Russian language. These are the number of native speakers, the number of language learners, the economic power of the countries that use the language, the number of professional fields where the language is important, the number and population of the countries using the language, the social and literary prestige of the language, as well as its official status in the UN.

To determine the perspective directions of the development of this activity, we have analyzed the named parameters of the influence of the language, goals, tasks and main priorities contained in existing state documents (The Principles of the State Cultural Policy, The Strategy of the State Cultural Policy till 2030, The Federal Purpose Programme "The Russian Language", etc.). On the basis of these documents the authors determined the adequacy and completeness of the state's policy in the promoting and supporting of the Russian language in order to form an authentic image of the Russian world.

In spite of the significance and obvious polydirectionality of the state policy in the sphere of the Russian language, the list of the state projects should be completed considering the acute and desired image of the Russian world and the criteria of the language importance. This will help to increase the effectiveness of the policy in this area.

Keywords: Russian world; Russian language; state policy; soft power

\section{REFERENCES}

Kontseptsiia gosudarstvennoi podderzhki i prodvizheniia russkogo iazyka za rubezhom (2015). Prezident Rossii [online] Available at: http://kremlin.ru/acts/news/50644 (access date: 03.05.2017). (In Russ.).

Ob utverzhdenii federal'noi tselevoi programmy «Russkii iazyk» na 2016-2020 gody (2015). Pravitel'stvo Rossii [online] Available at: http://government.ru/docs/18169/ (access date: 03.05.2017). (In Russ.).

Ukaz Prezidenta Rossiiskoi Federatsii ot 24 dekabria 2014 g. № 808 «Ob utverzhdenii Osnov gosudarstvennoi kul'turnoi politiki» (2014). Prezident Rossii [online] Available at: http://kremlin.ru/ acts/bank/39208 (access date: 03.05.2017). (In Russ.).

Apresian, Iu. D. (1995) Obraz cheloveka po dannym iazyka: popytka sistemnogo opisaniia. Voprosy iazykoznaniia, no. 1, pp. 7-15. (In Russ.).

Aref'ev, A. L. (2012) Russkii iazyk na rubezhe XX-XXI vekov. Tsentr sotsial' nogo prognozirovaniia $i$ marketinga [online] Available at: https://www.civisbook.ru/files/File/rus-skij_yazyk.pdf (access date: 03.05.2017). (In Russ.).

Astaf'eva, O. N. (2008) Mezhkul'turnyi dialog v usloviiakh globalizatsii: problemy teorii i praktiki. In: Mezbkul' turnyi i mezhreligioznyi dialog v tseliakb ustoichivogo razvitiia: Materialy Mezhdunarodnoi konferentsii / ed. by V. K. Egorova. Moscow, RAGS Publ. Pp. 120-138. (In Russ.).

Astaf'eva, O. N. (2011) Russkii iazyk v kontekste sovremennykh strategii i praktik kul'turnoi politiki. In: Kirillitsa: ot vozniknoveniia do nashikb dnei. St. Petersburg, Aleteiia. Pp. 419-443. (In Russ.).

Astaf'eva, O. N. (2013) Kul'turnaia politika: teoreticheskie aspekty i praktika realizatsii. Sovre-mennaia nauka: aktual'nye problemy teorii i praktiki. Seriia: Gumanitarnye nauki, no. 1-2, pp. 22-29. (In Russ.).

Astaf'eva, O. N. (2015) Mezhkul'turnye kommunikatsii i kollektivnaia identichnost': novye aktsenty v kul'turnoi politike natsional'nykh gosudarstv. XV Mezhdunarodnye Likbachevskie nauchnye chteniia, 2015 god. "Sovremennye global'nye vyzovy i natsional' nye interesy»: materialy $i$ vystupleniia [online] Available at: http://www.lihachev.ru/pic/site/files/lihcht/2015/dokladi/AstafjevaON_sec2_rus_izd.pdf (access date: 13.05.2017). (In Russ.).

Astaf'eva, O. N. (2016) Mezhkul'turnyi dialog v kontekste traditsii i novatsii: soglasovanie individual'nykh i kollektivnykh diskursov. In: Rossiia: gosudarstvo $i$ obsbchestvo $v$ novoi real'nosti : sb. statei Mezbdunarodnoi nauchno-prakticheskoi konferentsii IGSU RANKbiGS : in 3 vol. Moscow, RANKhiGS. Vol. 3. 528 p. Pp. 133-139. (In Russ.). 
Kozlovtseva, N. A. (2017) Programmy i proekty po prodvizheniiu i podderzhke russkogo iazyka v strukture gosudarstvennoi politiki Rossiiskoi Federatsii . In: Sb. statei Mezbdunarodnoi nauchnoprakticheskoi konferentsii «Gosudarstvennoe upravlenie i razvitie Rossii: modeli $i$ proekty». Moscow, Prospekt. Vol. 3. 840 p. Pp. 253-260. (In Russ.).

Likhachev, D. S. (1993) Kontseptosfera russkogo iazyka. Izvestiia Akademii nauk. Seriia literatury $i$ iazyka, vol. 52, no. 1, pp. 3-9. (In Russ.).

Novye dannye o vostrebovannosti russkogo iazyka za rubezhom (2016). Gosudarstvennyi institut russkogo iazyka im. A. S. Pushkina [online] Available at: http://www.pushkin.institute/news/detail. php? ID=4942 (access date: 03.05.2017). (In Russ.).

Prokhorov, Iu. E. (1996) Natsional' nye sotsiokul'turnye stereotipy rechevogo obshcheniia $i$ ikb rol' v obuchenii russkomu iazyku inostrantsev. Moscow, Pedagogika-Press. 216 p. (In Russ.).

Smysly i tsennosti Russkogo mira (2010): sb. statei i materialov kruglykh stolov, organizovannykh fondom «Russkii mir» / ed. by V. Nikonov. Moscow, Russkii mir. 112 p. (In Russ.).

10 samykh vliiatel'nykh iazykov mira. Biuro perevodov «Prima Vista». [online] Available at: http://www.primavista.ru/rus/catalog/vliyatelnye_yazyki (access date: 03.05.2017). (In Russ.).

Gross domestic product based on purchasing-power-parity (PPP) valuation of country GDP (2016). The World Bank [online] Available at: http://data.worldbank.org/indicator/NY.GDP. MKTP.PP.CD (access date: 03.05.2017).

OECD proposes new approach to assess young people's understanding of global issues and attitudes toward cultural diversity and tolerance. OECD [online] Available at: https://www.oecd.org/ pisa/oecd-proposes-new-a pproach-to-assess-young-peoples-understanding-of-global-issues-andattitudes-toward-cultural-diversity-and-tolerance.htm (access date: 22.04.2017).

Overall Ranking (2016). The Soft Power 30 [online] Available at: http://softpower30.portlandcommunications.com/ranking/ (access date: 03.05.2017).

Nye, Jr. and Joseph, S. (2004) Soft Power. The means to success in world politics. N. Y., Public Affairs. 193 p.

Ronen, Sh., Gonçalves, B., Hu, K., Vespignani, A., Pinker, S. and Hidalgo, C. (2014) Links that speak: The global language network and its association with global fame. Proceedings of the National Academy of Sciences of the United States of America, vol. 111, no. 52. DOI: 10.1073/pnas.1410931111

Summary by language size. Ethnologue: Languages of the World [online] Available at: http:// www.ethnologue.com/statistics/size (access date: 22.04.2017)

Weber, G. (1997) The world's 10 most influential languages. Language Montbly, no. 3, pp. 12-18.

Submission date: 12.05 .2017$.

Астафьева Ольга Николаевна - доктор философских наук, профессор, директор Научно-образовательного центра «Гражданское общество и социальные коммуникации» Российской академии народного хозяйства и государственной службы при Президенте РФ; почетный работник высшего профессионального образования Российской Федерации. Адрес: 119606, Россия, г. Москва, пр-т Вернадского, д. 8. Тел.: +7 (499) 956-94-28. Эл. адрес: onastafieva@mail.ru

Козловцева Нина Александровна - аспирантка Научно-образовательного центра «Гражданское общество и социальные коммуникации» Российской академии народного хозяйства и государственной службы при Президенте РФ; ассистент Аепартамента языковой подготовки Финансового университета при Правительстве РФ. Адрес: 119606, Россия, г. Москва, пр-т Вернадского, А. 8. Тел.: +7 (499) 956-94-28. Эл. адрес: ninelkorch@yandex.ru. Научный руководитель - А-р филос. наук, проф. О. Н. Астафьева.

Astafieva Olga Nikolaevna, Doctor of Philosophy, Professor, Director, Scientific and Educational Centre "Civil Society and Social Communications", the Russian Presidential Academy of National Economy and Public Administration; honorary worker of higher professional education of the Russian Federation. Postal address: 8, Vernadskogo Ave., Moscow, Russian Federation 119606. Tel.: +7 (499) 956-94-28. E-mail: onastafieva@mail.ru 
Kozlovtseva Nina Aleksandrovna, Postgraduate Student, Scientific and Educational Centre "Civil Society and Social Communications", the Russian Presidential Academy of National Economy and Public Administration; Assistant, Department of Language Training, Financial University under the Government of the Russian Federation. Postal address: 8, Vernadskogo Ave., Moscow, Russian Federation 119606. Tel.: +7 (499) 956-94-28. E-mail: ninelkorch@yandex.ru. Scientific Adviser: O. N. Astafieva, Doctor of Philosophy, Professor. 